\title{
ANALISIS DAMPAK COVID-19 TERHADAP PERKEMBANGAN UMKM (STUDI KASUS : HOME INDUSTRI KOPI SIKARTA) DI DESA SIALANG KECAMATAN BANGUN PURBA KABUPATEN DELI SERDANG
}

\author{
Rahayu Sri Utami ${ }^{1}$, Handeo Ginting ${ }^{2^{*}}$, Muhammad Khairil ${ }^{3}$ \\ Departemen Manajemen Informatika ${ }^{1}$, Program Studi Manajemen Informatika ${ }^{2.3}$ \\ AMIK Widya Loka Medan \\ Perumnas BSP Kecamatan Lubuk Pakam \\ Dusun 3 Desa Sibaganding Kecamatan Bangun Purba \\ Desa sementara dusun IV Kecamatan Pantai Cermin \\ rahayusriutami891@gmail.com, Khairilmuhammad363@gmail.com
}

\begin{abstract}
ABSTRAK
Penelitian ini bermaksud untuk menganalisa dampak Covid-19 terhadap perkembangan Usaha Mikro, Kecil, dan Menengah di Kabupaten Deli Serdang, Kecamatan Bangun Purba, Desa Sialang. Penelitian ini dilakukan selama pandemic Covid-19 dalam rentang waktu bulan April sampai Juli 2021. Populasi peneilitian ini yaitu Usaha Mikro, Kecil, dan Menengah yang ada di Kabupaten Deli Serdang. untuk menganalisi data penelitian ini menggunakan analisis regresi linier sederhana untuk melihat ada tidaknya pengaruh dari Covid-19 terhadap perkembangan Usaha Mikro, Kecil, Menengah di Kabupaten Bangun Purba, dimana besaran pengaruhnya adalah $4,1 \%$.
\end{abstract}

\section{Kata Kunci ; Covid-19; UMKM}

Abstract: This xtudy intends to analyze the impact of Covid-19 on the development of Micro, Small and Medium Enterprises in Deli Serdang. this researchnwas conducted during the Covid-19 pandemic in the periode april to may 2021. The population of this research is Mikro, Small and Medium Enterprises in Deli Serdang, where the sample of this study amounted to 150 taken with quota sampling technigues. To analyze the data of this study using simple linear reqression analysis to see whether there is an influence od Covid-19 on the development of Micro, Small and Medium Enterprises in Deli Serdang Regency. The results showed that covid-19 had a negative influence on the development of Micro, Small and Medium Enterprises in Deli Serdang Regency, where of influence was 41\%.

Keyword: Covid-19; UMKM 


\section{Latar Belakang Masalah}

Di awal tahun 2020, dunia di gemparkan dengan merabaknya virus baru yaitu coronavirus (SARS-CoV) dan penyakit disebut Coronavirus di sease 2019 (COVID-19). Covid-19 adalah penyakit menular yang merupakan keluarga besar virus yang menyebabkan penyakit ringan sampai berat, dari mulai pilek sampai dengan penyakit serius seperti MERS dan SARS.

WHO menyatakan bahwa covid-19 menular melalui orang yang terinfeksi coronavirus. Virus tersebut menyebar melalui droplet yang keluar saat batuk atau bersin. Selanjut nya, droplet yang mengandung coronavirus dapat mendarat dipermukaan benda yang mungkin di sentuh oleh orang yang sehat. Jika di tangan orang yang sehat terdapat coronavirus dan kemudian menyentuh hidung, mulut atau mata, maka orang tersebut akan terpapar coronavirus. Coronavirus itu sifat nya zoonotik yaitu penyakit pada hewan yang bisa menyebar ke manusia. Namun, pada SARS COV-2 bisa menular dari satu orang ke orang yang lainnya Diketahui, asal mula virus ini berasal dari Wuhan, Tiongkok. Diketahui pada akhir Desember tahun 2019 . sampai saat ini sudah di pastikan terdapat 65 negara lebih yang telah terjangkit virus ini termasuk di Indonesia (data WHO, 1 Maret 2020) (PDPI, 2020).1

Saat ini total jumlah pesien positif virus corona (Covid-19) di Indonesia hingga selasa (11/5) berjumlah 14.265 kasus. Sebanyak 991 diantarannya meninggal dunia 2.881 orang di nyatakan sembuh. Juru bicara pemerintah khusus penanganan covid-19 Achmad Yurianto mengatakan jumlah tersebut merupakan data yang di peroleh pemerintah hingga selasa $(11 / 5) .2$

\section{Rumusan Masalah}

1. Bagaimana dampak yang ditimbulkan dari Covid-19 di Sektor Ekonomi khususnya di bidang UMKM di Desa Sialang produksi kopi sikarta!

2. Bagaimana Peran UMKM dalam menangani di masa pandemic !

\section{Batasan Masalah}

1. Kendala apa saja yang ditimbulkan akibat virus Covid-19 di sector ekonomi

2. Upaya UMKM untuk bertahan dan meningkatkan perekonomian selama pandemic Covid-19

\section{Tujuan Penelitian}

1. Untuk mengetahui solusi apa saja yang harus dilakukan wirausaha dalam menangani dampak yang ditimbulkan dari Covid-19 di sector Ekonomi

2. Solusi apa saja yang dilakukan UMKM di masa Pandemi

\section{Metode Penulisan}

Metode penulisan ini adalah deskriptif, yang jenis penelitian menyajikan klarifikasi jenis atau garis besar tahapan mendokumentasikan dan melaporkan pengaruh keberadaan Covid-19 yang telah memberikan pengaruh terhadap perekonomian UMKM. 
Hal ini sontak membuat banyak pihak mengeluh karena merasa rugi. Termasuk UMKM yang berada di Kabupaten Deli Serdang baik yang bermitra dengan jasa trasportasi online atau tidak, walaupun sudah di pastikan bahwa di Kabupaten Deli Serdang belum terdapat pasien yang terkena positif virus corona, tetapi kewaspadaan dan kepanikan masyarakat di Kabupaten Deli Serdang sangat berpengaruh pada perkembangan UMKM yang ada di Kabupaten Deli Serdang.

Bertitik tolak dari latar belakang yang telah dijelaskan di atas, maka penulis mencoba melakukan penelitian dengan judul: "Analisis Dampak Covid-19 Terhadap Perkembangan UMKM (Studi Kasus : Home Industri Kopi Sikarta) di Desa Sialang Kecamatan Bangun Purba Kabupaten Deli Serdang"

Salah satu lapangan usaha yang telah mendorong pertumbuhan ekonomi dan mengurangi angka kemiskinan serta menjadi konsen pemerintah padan Usaha Mikro kecil, dan Menengah (UMKM). Dimana dalam Undang-undang Republik Indonesia Nomor 20 Tahun 2008 tentang Usaha Mikro, Kecil, dan Menengah, passal 3 menyebutkan bahwa UMKM memiliki tujuan menumbuhkan dan mengembangkan usahanya dalam rangka membangun perekonomian nasional berdasarkan demokrasi ekonomi yang berkeadilan. Dalam mewujudkan tujuan tersebut menurut Humas Kementrian Koperasi dan Usaha Kecil Menengah (Humas kemenkop dan UKM, 2019) perlu adanya transformasi ekonomi dalam mewujudkan struktur ekonomi yang ada dan berkembang di Indonesia saat ini masih di dominasi oleh pelaku usaha mikro yang berjumlah 63, 5 juta unit, usaha kecil 783.132 unit, usaha menengah 60.702 unit, serta usaha besar 5.550 unit. Sehingga transformasi struktur ekonomi UMKM menjadi perwujudan tujuan UMKM dalam menumbuhkan dan mengembangkan UMKM untuk membangun perekonomian nasional. Saat ini perekonomian Indonesia telah mengalami guncangan pada masa pandemic Covid-19 yang merupakan isu global dan dipandang berdampak pada krisis global multidimensi. Goncangan dan krisis pada masa pandemic Covid-19 menurut laporan pers Humas Kemenkop dan UKM telah memberikan dampak besar terhadap pelaku usaha, dan 99\% pelaku usaha tersebut adalah UMKM (depkop.go.id, 2020). Dampak perekonomian pada sector UMKM tersebut menurut Fathoni (2020;38-39) tidak sedikit PHK, banyak karyawan dirumahkan, menurunnya volume dan omset penjualan. Menurunnya jumlah pembeli UMKM, Harga APD melangit, Vitamin C naik harga, bahan pokok naik harga, beberapa pasar ditutup, dan UMKM terancam bangkrut atau gulung tikar. Kondisi tersebut menunjukan keterpurukan UMKM yang telah terlihat sejak awal sebaran Covid-19, selain itu juga diperkuat dengan munculmnya kebijakan pemberlakuan PSBB dan pemerintah dalam masa pandemic Covid-19 juga memberikan dampak pada bidang social, budaya, dan ekonomi.

Dalam upaya mengintensifikasikan perekonomian UMKM, pemerintah telah menetapkan lima langkah kebijakan dalam menyelesaikan permasalahan UMKM yang terpuruk di tengah pandemic Covid-19. Lima langkah kebijakan pemerintah tersebut seperti yang dijelaskan oleh Humas Kemenkop UKM yaitu : pertama, mendorong 98\% pelaku usaha mikro dan ultra mikro untuk masuk ke dalam kelompok miskin baru agar mendapatkan bantuan social. Kedua, penundaan cicilan dan bunga hingga 6 bulan. Ketiga, pembiayaan UMKM dan koperasi melalui Kredit usaha Rakyat (KUR). Keempat, mendorong agar belanja pemerintah diprioritaskan bagi produk UMKM. Kelima, UMKM harus berinovasi dan 
beradaptasi dengan market baru (depkop.co.id, 2020). Langkah pemerintah tersebut juga sesuai dengan pemerdayaan UMKM agar menjadi usaha yang tangguh dan mandiri selama masa pandemic Covid-19.

Dalam menjaga kekuatan dan kemandirian UMKM selama masa pandemic Covid-19, dari hasil penelitian PakPahan (2020) menawarkan dua bentuk kebijakan terhadap UMKM yaitu kebijakan jangka pendek dan jangka panjang. Kebijakan jangka pendek yang dapat diterapkan adalah bantuan keuangan baik dalam bentuk pinjaman lunak atau bantuan tunai langsung dengan melibatkan pemerintah dan sector swasta. Sementara strategi jangka panjang difokuskan pada pengenalan dan penggunaan teknologi digital bagi UMKM sekaligus persiapan untuk memasuki era Industri 4.0. Strategi jangka panjang tersebut juga sesuai dengan arah Kemekop UKM, bahwa masa pandemic Covid-19 diharapkan dapat menjadi momentum untuk mempercepat digitalisasi UMKM di Indonesia, dan saat ini baru $13 \%$ UMKM yang masuk dalam ekosistem digital (depkop.go.id,2020). 10 persen langgeng dalam ekosistem baru tersebut. Mengingat bahwa beberapa pelaku usaha dan UMKM yang mampu bertahan dan mengalami peningkatan pada masa pandemic Covid-19 adalah bidang usaha terutama yang terhubung dengan ekosistem digital (depkop.go.id,2020). Maka proses percepatan digitalisasi UMKM di Indonesia dapat menjadi salah satu upaya pemerintah dan juga UMKM untuk mampu bertahan dan meningkatkan perekonomian selama pandemic Covid-19.

\section{Tinjauan Pustaka. UMKM}

Usaha Mikro, keci dan Menangah adalah salah satu bagian penting dari perekonomian suatu bangsa. Sehingga perlu dukungan dari berbagai kalangan seperti sumber daya manusia (SDM) sebagai pelaku penguat UMKM. Karena peran pentingnya tersebut pemerintah terus melakukan supaya mengembangkan UMKM.

Adapun cirri-ciri UMKM adalah menggunakan teknologi sederhana atau manual sehingga mudah dilakukan alih teknologi, bahan baku mudah diperolehnya, memiliki keterampilan dasar umumnya didapat secara turun temurun peluang pasar cukup luas, bersifat padat karya atau menyerap tenaga kerja yang cukup banyak, sebagian besar produknya dipasarkan di pasar local atau domestic dan tidak tertutup sebagian lainnya berpontensi untuk diekspor (Halim, 2009).

Pada pasal 19 UU No. 20 Tahun 2008 tentang UMKM, dalam pasal 16 ayat (1) huruf c pengembangan dalam bidang sumber daya manusia dilakukan dengan cara :

a. Memberdayakan kewirausahaan

b. Meningkatkan keterampilan secara teknis agar suatu usaha bisa berkembang dengan baik.

c. Membuat pelatihan tentang UMKM agar bisa motivasi kreativitas bisnis, dan penciptaan wirausaha baru (Feni Dwi Anggraeni \& Hayat, 2018). 
Dilihat dari karakteristiknya UMKM antara lain :

1. Tidak adanya pembagian tugas yang jelas pada bidangnya, biasanya pemilik usaha merenangkap tugas dalam pengoprasian

2. Rendahnya akses industry kepada kredit formal, sehingga modal usaha mereka kebanyakan murni dari modal pribadi maupun kerabat keluarga

3. Usaha kecil sebagian besar belum mempunyai izin badan hukum

4. UMKM sebagian besar bergerak pada usaha minuman, makanan dan tembakau. (Hafni).

\section{Metode Penelitian}

Penelitian ini dilakukan disalah satu usaha produksi kopi Sikarta yang dikelola Agung Sasmita yang beradi di desa Sialang Kecamatan Bangun Purba, Kabupaten Deli Serdang. dengan menggunakan metode kualitatif untuk medeskripsikan bagaimana keadaan usaha saudara Agung dimasa pandemic ini dengan pendekatan Analisis SWOT. Yang mana masa pandemic banyak usaha kecil yang mengalami penurunan pendapatan.

Untuk mendapatkan data primer kami melakukan wawancara dengan prilaku usaha. Sedangkan data sekunder didapatkan melalui karya ilmiah dan juga jurnal yang ada pada webside resmi.

\section{E-Marketing}

Menurut (Chaffey, 2009) e-marketing memiliki cakupan yang lebih luas karena mengacu kepada penggunaan berbagai teknologi untuk mencapai tujuan pemasaran dan memiliki perspektif internal dan eksternal. E-marketing merupakan bagian dari e-business yang berorientasi kepada pelanggan11. Kotler dan Armstrong (2012) menyatakan bahwa emarketing merupakan upaya perusahaan dalam menginformasikan, mengkomunikasikan dan mempromosikan serta memasarkan produk dan jasanya melalui internet. E-marketing adalah proses membangun dan memelihara hubungan dengan pelanggan melalui aktifitas online. Secara singkat, e-marketing dapat diartikan sebagai proses pemasaran secara online untuk memasarkan barang dan jasa serta bertujuan untuk membangun, mempertahankan hubungan dan memberikan kepuasan pada pelanggan.

\section{Penggunaan E-Marketing}

Carniels et al, (2014) menjelaskan bahwa penggunaan internet oleh UMKM memudahkan pertukaran informasi secara instan merangsang efisiensi dan membantu memecahkan masalah sejak tahap awal. Penggunaan social media dinilai memberikan dampak positif terhadap suatu bisnis, khususnya dapat mengurangi biaya pemasaran yang cukup besar dan meningkatkan hubungan baik dengan pelanggan.

Peran e-marketing pada era digital memungkinkan perusahaan dan setiap individu di dalam perusahaan untuk melakukan networking dengan perusahaan lain di seluruh dunia.13 Penggunaan e-marketing dapat digolongkan menjadi 2 (dua) bagian, yaitu:

a) Sumber Penghasilan: Para pelaku usaha melihat adanya gaya hidup masyarakat ditengah perkembangan teknologi dimana penggunaan teknologi seperti smartphone 
oleh masyarakat semakin meningkat. Hal ini yang kemudian mendorong pelaku usaha untuk menjalankan e-marketing sebagai sumber penghasilan.

b) Media Promosi: Seiring dengan semakin ketatnya persaingan bisnis di era digitalisasi saat ini, promosi tidak hanya dilakukan secara offline namun juga dapat dilakukan scara online. Adapun promosi online merupakan salah satu bentuk dari kegiatan emarketing. Penggunaan internet merupakan salah satu cara yang efektif untuk membangun brand dan menjadikan bisnis dikenal banyak orang.

c) Sumber Penghasilan: Para pelaku usaha melihat adanya gaya hidup masyarakat ditengah perkembangan teknologi dimana penggunaan teknologi seperti smartphone oleh masyarakat semakin meningkat. Hal ini yang kemudian mendorong pelaku usaha untuk menjalankan e-marketing sebagai sumber penghasilan.

d) Media Promosi: Seiring dengan semakin ketatnya persaingan bisnis di era digitalisasi saat ini, promosi tidak hanya dilakukan secara offline namun juga dapat dilakukan scara online. Adapun promosi online merupakan salah satu bentuk dari kegiatan emarketing. Penggunaan internet merupakan salah satu cara yang efektif untuk membangun brand dan menjadikan bisnis dikenal banyak orang.

\section{Hasil dan Pembahasan Peran UMKM}

Usaha mikro kecil dan menengah mrupakan pemain utama dalam kegiatan ekonomi di Indonesia. Masa depan pembangunan terletak pada kemampuan usaha mikro kecil dan menengah untuk berkembang mandiri. Diakui, bahwa Usaha Mikro, Kecil dan Menengah (UMKM) memainkan peran penting di dalam pembangunan dan pertumbuhan ekonomi. Secara umum UMKM dalam perekonomian nasional memiliki peran; (1) sebagai pameran utama dalam kegiatan ekonomi, (2) 20 penyedia lapangan kerja terbesar, (3) pemain penting dalam kegiatan pengembangan perekonomian local dan pemerdayaan mayarakat, (4) pencipta pasar baru dan sumber inovasi, serta (5) kontribusinya terhadap neraca pembayaran (Departemen Koperasi).

\section{Strategi UMKM Indonesia Di Masa Pandemi Covid-19}

Strategi pandemic Covid-19 yang terjadi saat ini selain dianggap sebagai bencana, wabah yang membawa kerugian pada berbagai sisi kehidupan dan perekonomian bangsa namun juga memberikan tantangan sekalugus peluang bagi pemerintahan dalam menjaga eksitensi UMKM dan para perkerja yang berada di dalam UMKM tidak hanya sekedar bertahan namun juga dapat mengembangkan usahanya dan menjadi penopang yang kuat bagi perekonomian Indonesia.

Strategi jangka pendek yang dilakukan pemerintah antara lain :

1. Berkaitan dengan penerapan protocol kesehatan yang ketat sebagaimana petunjuk dan arahan yang dianjurkan oleh pemerintah melalui kementrian Kesehatan Indonesia dan gugus Tugas Penanganan Covid-19. UMKM harus menjalankan protocol kesehatan secara ketat dalam menjalankan aktivitas ekonominya. Sebagaimana diketahui bahwa 
mengahadapi masa new normal. Pemerintahan telah mengizinkan UMKM untuk kembali beroperasi dengan beberapa syarat dan ketentuan diantaranya yaitu penerapan protocol kesehatan secara ketat dengan menyediakan fasilitas mencuci tangan, hand sanitizer, pengecekan suhu badan, pembatasan jumlah pengunjung.

2. Pemerintahan dapat memberikan ruangan dan dukungan bagi perkembangan layanan diqital di UMKM karena dapat mengurangi interaksi fisik maupun tetap dapat melaksanakan proses transaksi.

3. Menguatkan peran-peran Asosiasi pelaku usaha seperti Apindo, Kadin, dan IPMI dalam mensosialisasi kebijakan pemerintah agar kebijakan-kebijakan tersebut cepat terserap dan UMKM cepat tertolong.

4. Melakukan penyederhanaan administrasi terkait dengan kebijakan pelonggaran atau penundaan pembayaran kredit bagi UMKM.

5. Melakukan pembinaan kepada UMKM dengan mendorong UMKM harus berinovasi dan menyesuaikan strategi bisnis dengan situasi yang sedang dihadapi. Misalnya saat sebelum pandemic Covid-19 biasanya UMKM yang berjualan makanan bisa beralih kepada berjualan makanan Frozen yang ternyata lebih banyak diminati selama masa pandemic seperti saat ini.

Dengan adanya Analisis SWOT hasil pembahasan dari penelitian ini adalah agar bisa membuat strategi dalam mengembangkan suatu usaha :

1. Strategths (kekuatan). Dengan tidak adanya pesaing pengusaha terus berinovasi seperti meningkatkan pelayanan usaha seperti pada segi kebersihan pada tempat usaha paket kuliner, dan tata letak ruangan yang nyaman

2. Weekness (kelemahan), penjualan yang dilakukan dengan sistem offline membuat pembeli tidak bisa berkembang. Sehingga pengusaha mengikuti pelatihan tentang inovasi usaha yang diadakan oleh pelaku usaha lain maupun pemerintah.

3. Opportunities (peluang) dengan minat pembeli yang semakin sedikit. Maka pengusaha harus semakin aktif terlibat dalam kegiatan yang dilakukan oleh pemerintah maupun usaha kuliner yang lain.

4. Theats (ancaman), pendapat yang terus menurun membuat modal tidak bisa berputer dengan baik dan bahan baku yang terus naik, sehingga pengusaha harus bisa mensiasati kenaikan bahan baku dengan berkerja sama dengan pengusaha kuliner lain untuk menjadi supplier bahan baku.

Jika dilihat dari analisis SWOT diatas usaha ibu Andri harus terus melakukan movasi baru agar tidak kalahn bersaing dengan jajanan modern dan terus aktif mengikuti pelatihan yang dilakukan oleh pemerintah setempat maupun kelompok usaha lain agar jaringan usaha lebih luas.

Kebanyakan permasalahan yang dihadapi dalam UMKM adalah masalah permodalan. Sehingga diperlukan cara lain supaya sektor UMKM lebih berkembang lagi. Baik melalui aspek pemasaran maupun distribusi. Dari segi pemasaran. Dengan cara memanfaatkan kemajuan teknologi informasi yang sedang berkembang pesat saat ini. Dengan penggunaan internet di Indonesia yang cukup pesat dari tahun ke tahun. Penjualan produk 
secara online adalah salah satu cara yang baik untuk memasarkan produk UMKM (Permana 2017). Akan tetapi pada masa pandemic Covid-19 ini strategi pemasaran produk harus dilakukan secara online juga seperti halnya mendaftarkan UMKM ke situs Gofood maupun Grabfood. Karena sedikitnya aktivitas masyarakat diluar rumah para pengusaha harus membuat inovasi baru agar produknya bisa dinikmati oleh banyak orang dengan mematuhi protokol kesehatan.

\section{Kesimpulan} berikut :

Dari pembahasan pada beberapa bab di atas, maka dapat diambil kesimpulan sebagai

1. Kondisi pandemic Covid-19 yang terjadi di Indonesia dan diberbagai negara di dunia telah menyebabkan berbagai negara di dunia telah menyebabkan berbagai negara di dunia telah menyebabkan berbagai permasalahan di bidang kesehatan dan juga perekonomian Indonesia juga mengalami gangguan yakni terjadinya penurunan pertumbuhan.

2. UMKM sebagai penopang perekonomian di Indonesia ternyata merupakan sektor yang paling pertama dan berdampak oleh pandemic Covid-19.

3. Berbagai strategi kebijakan dab stimulus dikeluarkan oleh pemerintah untuk melindungi UMKM dari keterpurukan yang disebabkan oleh Covid-19. Melindungi UMKM dari keterpurukan yang disebabkan oleh Covid-19.

Stimulus tersebut seharusnya dapat dimanfaatkan oleh UMKM, pemerintah dan stakeholder sehingga pemulihan ekonomi dapat lebih cepat. Berdasarkan laporan yang telah dikumpulkan, terlihat bahwa kebijakan dan stimulus pemerintah tersebut mampu memperbaiki kondisi perekonomian yang jatuh dimasa awal pandemic Covid-19 walaupun belum sepenuhnya membaik..

\section{Saran}

Sebaiknya saudara agung mengikuti pelatihan-pelatihan yang diadakan pemerintah maupun pelaku usaha lain. Karena dengan adanya mengikuti pelatihan akan menambah jaringan supaya usahanya bisa dikenal lebih banyak orang. Dan saudara agung terus inovasi dalam mengembangkan usaha kopi Sikarta yang bisa dijual disitus online untuk memperluas pendistribusian dan pemasarannya agar lebih dikenal lebih banyak orang. Karena dimasa pandemic ini banyak aktifitas orang-orang dilakukan secara online, mulai kerja, sekolah, hingga belanja. 


\section{Daftar Pustaka}

[1] Amin, D.S (n.d). Pengembangan usaha Mikro KecilDan Menengah (UMKM) Berbasis Industri Kreatif Di Kota Malang. Jurnal ilmu ekonomi,9

[2] Feni Dwi Anggraeni, I H., H., \& Hayat, A. (20018). Pengembangan usaha micro, kecil dan menengah (UMKM) melalui fasilitas pihak eksternal dan potensi internal (studi kasus pada kelompok usaha kopi di desa sialang kecamatan bangun purba.

[3] Hafni, a.R. (n.d). Analisis usaha mikro, kecil dan menengah (UMKM) terhadap penyerapan tenaga kerja di Indonesia.9

[4] Halim, a,(2020). Pengaruh pertumbuhan usaha mikro, kecil dan menengah terhadap pertumbuhan ekonomi Kabupaten Deli Serdang . jurnal ilmiah ekonomi pembangunan.7

[5] Abdurrahman Firdaus Thaha, Dampak Covid-19 Terhadap UMKMdi Indonesia, Jurnal Brand, Volume 2 No. 1, Juni 2020, diakses melalui https://ejournals.umma.ac.id/index.php/brand/article/view/607

[6] Agatha Olivia Victoria, Sri Mulyani Sebut Covid-19 LebihKompleks dari Krisis 1998 dan 2008, katadata.co.id: Finansial, Makro, 7 April 2021, diakses melalui https://katadata.co.id/happyfajrian/finansial/5e9a41f631b5e/sri-mulyani- sebut-covid19-lebih-kompleks-dari-krisis-1998-dan-2008

[7] Aisyah Nur Afifah, Penerapan Digital Marketing dan Pengaruhnya Terhadap Keberhasilan Usaha Mikro, Kecil dan Menengah Sektor Kreatif di Indonesia dan Malaysia, Bogor: Jurnal Sekolah Pasca Sarjana Institut Pertanian Bogor, 2018

[8] Anisya Al Faqir, Ekonomi Indonesia Diprediksi Tumbuh Minus 0,4 Persen Sepanjang 2021, Merdeka.com: Uang, Juli 2021, diakses melalui https://www.merdeka.com/uang/ekonomi-indonesia-diprediksi-tumbuh- $\quad \underline{\text { minus-04- }}$ persen-sepanjang-2021.html

[9] Dave Chaffey, E-Business and E-Commerce Management, England: Pearson Education Limited

[10] Estro Dariatno Sihaloho, Dampak Covid-19 Terhadap Perekonomian Indonesia, ResearchGate, April 2020, diakses melalui DOI:10.13140/RG.2.2.14524.67205

[11] Fadel Prayoga, 5 Jenis UMKM yang Paling Terdampak Covid-19, Okezone.com: Oke Finance, Ekonomy, Sektor Rill, 15 Juli 2020, diakses melalui https://economy.okezone.com/read/2020/07/15/320/2246713/5- jenis-umkm-yang-palingterdampak-covid-19

[12] Faidah Umu Safuroh, Rektor UI Paparkan Konsep Pemulihan Ekonomi 2020-2021, Detik.com: Detik Finance, Juli 2021, diakses melalui https://finance.detik.com/beritaekonomi-bisnis/d-5079505/rektor-ui- paparkan-konsep-pemulihan-ekonomi-2020$\underline{2021}$

[13] Fred R David, Strategic Management: Concepts and Cases, England: Prentice Hall, 2008

[14] Gita Laras Widyaningrum, WHO Tetapkan COVID-19 Sebagai Pandemi Global, Apa Maksudnya? National Geographic Indonesia:Kesehatan, Maret 2021, 


\section{Jurnal Widya}

Volume 1, Nomor 1, April 2020: halaman 30-42

P-ISSN: 2746-5411

e-ISSN: 2807-5528

https://jurnal.amikwidyaloka.ac.id/index.php/awl

jurnal@amikwidyaloka.ac.id / editor.jurnalwidya@gmail.com

diaksesmalelui https://nationalgeographic.grid.id/read/132059249/who-tetapkancovid- 19-sebagai-pandemi-global-apa-maksudnya

[15] Gusti, Transaksi Penjualan Online Naik 400 Persen di Masa Pandemi Covid-19, Universitas Gadja Mada: Liputan/Berita, Mei 2020, diakses melalui https://ugm.ac.id/id/berita/19452-transaksi-penjualan-online-naik-400-persen-dimasa-pandemi-covid-19

[16] Haryanto, Dampak Covid-19 terhadap Pergerakan Nilai TukarRupiah dan Indeks Harga Saham Gabungan (IHSG), Jurnal: The Indonesian Journal of Development Planning, Volume IV No. 2 - Juni 2020 diakses melalui DOI: https://doi.org/10.36574/jpp.v4i2.114

[17] Haryati Puspa Sari, 425.796 Kasus Covid-19 di Indonesia, Waspadai Gelombang Kedua, dan Wanti-wanti Jokowi, diakses dari https://nasional.kompas.com/read/2020/11/06/08094281/425796-kasus-

\section{Dokumentasi :}

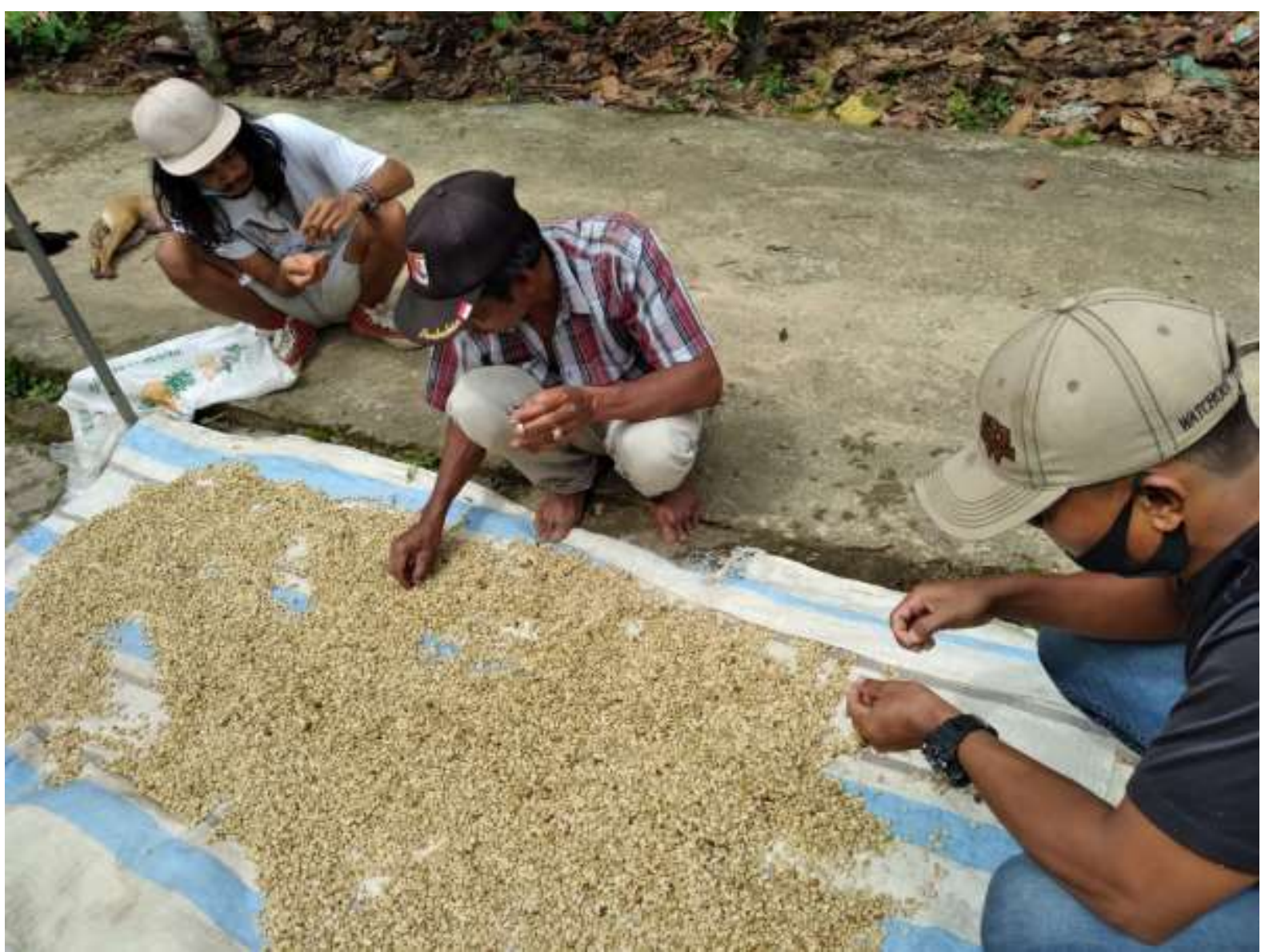

Proses Penjemuran Biji Kopi

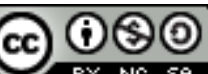

JURNAL WIDYA This work is licensed under a Creative Commons Attribution-NonCommercialShareAlike 4.0 International License. 


\section{Jurnal Widya}

Volume 1, Nomor 1, April 2020: halaman 30-42

https://jurnal.amikwidyaloka.ac.id/index.php/awl

jurnal@amikwidyaloka.ac.id/ editor.jurnalwidya@gmail.com

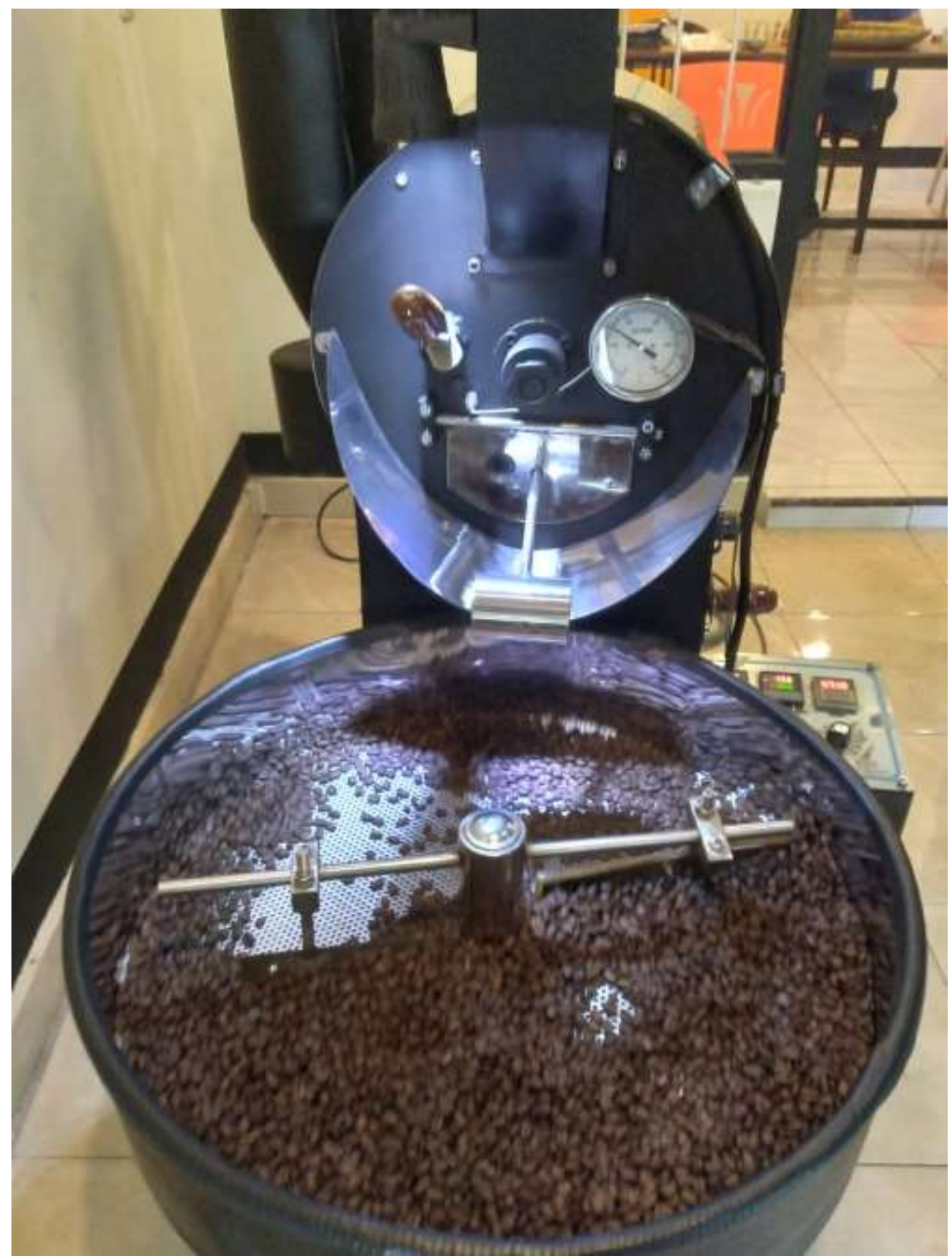

Proses Roasting Biji Kopi

\section{(c) (i) (2)}

JURNAL WIDYA This work is licensed under a Creative Commons Attribution-NonCommercialShareAlike 4.0 International License. 


\section{Jurnal Widya}

Volume 1, Nomor 1, April 2020: halaman 30-42

P-ISSN: 2746-5411

e-ISSN: 2807-5528

https://jurnal.amikwidyaloka.ac.id/index.php/awl

jurnal@amikwidyaloka.ac.id / editor.jurnalwidya@gmail.com

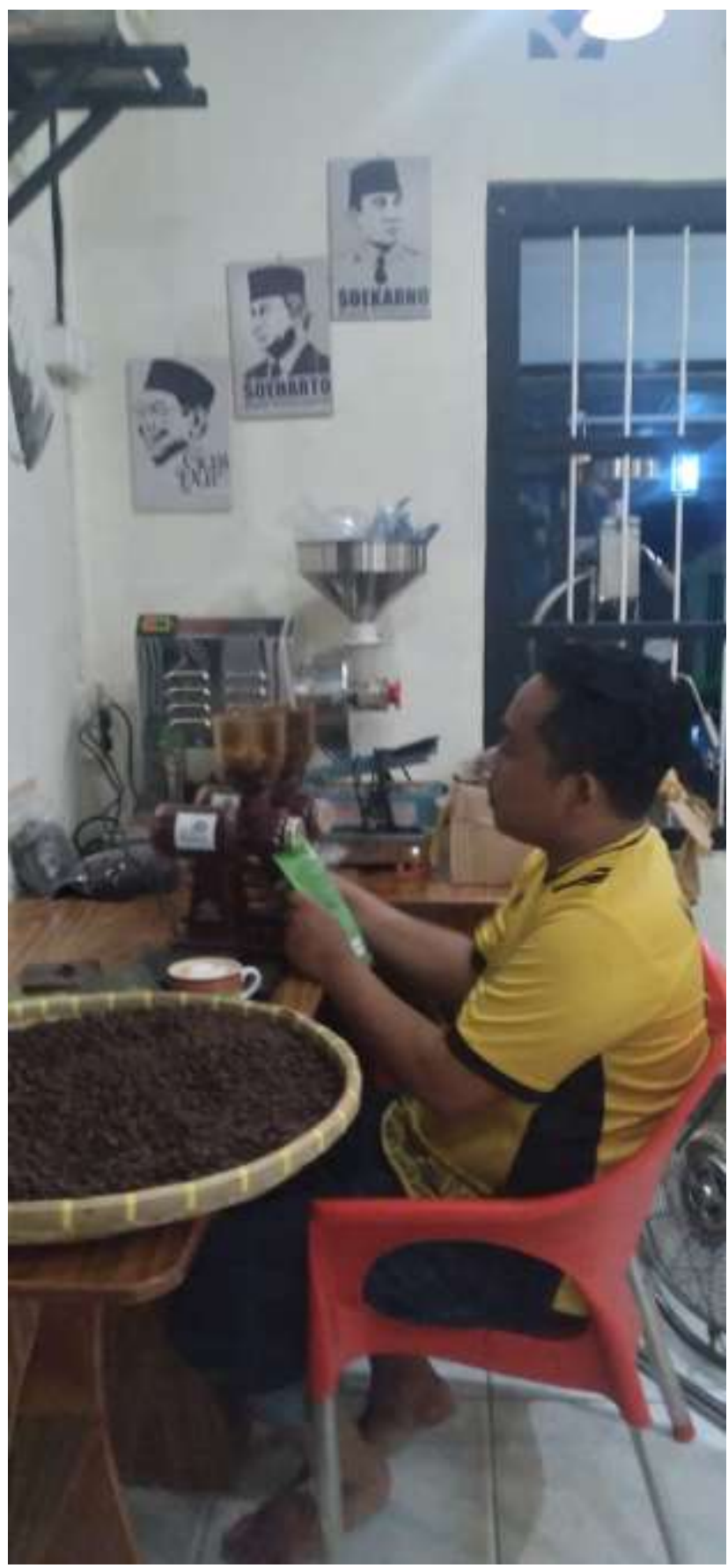

Proses Pengemasan Kopi

\section{(c) (i) (2)}

JURNAL WIDYA This work is licensed under a Creative Commons Attribution-NonCommercialShareAlike 4.0 International License. 


\section{Jurnal Widya}

Volume 1, Nomor 1, April 2020: halaman 30-42

P-ISSN: 2746-5411

https://jurnal.amikwidyaloka.ac.id/index.php/awl

jurnal@amikwidyaloka.ac.id/ editor.jurnalwidya@gmail.com

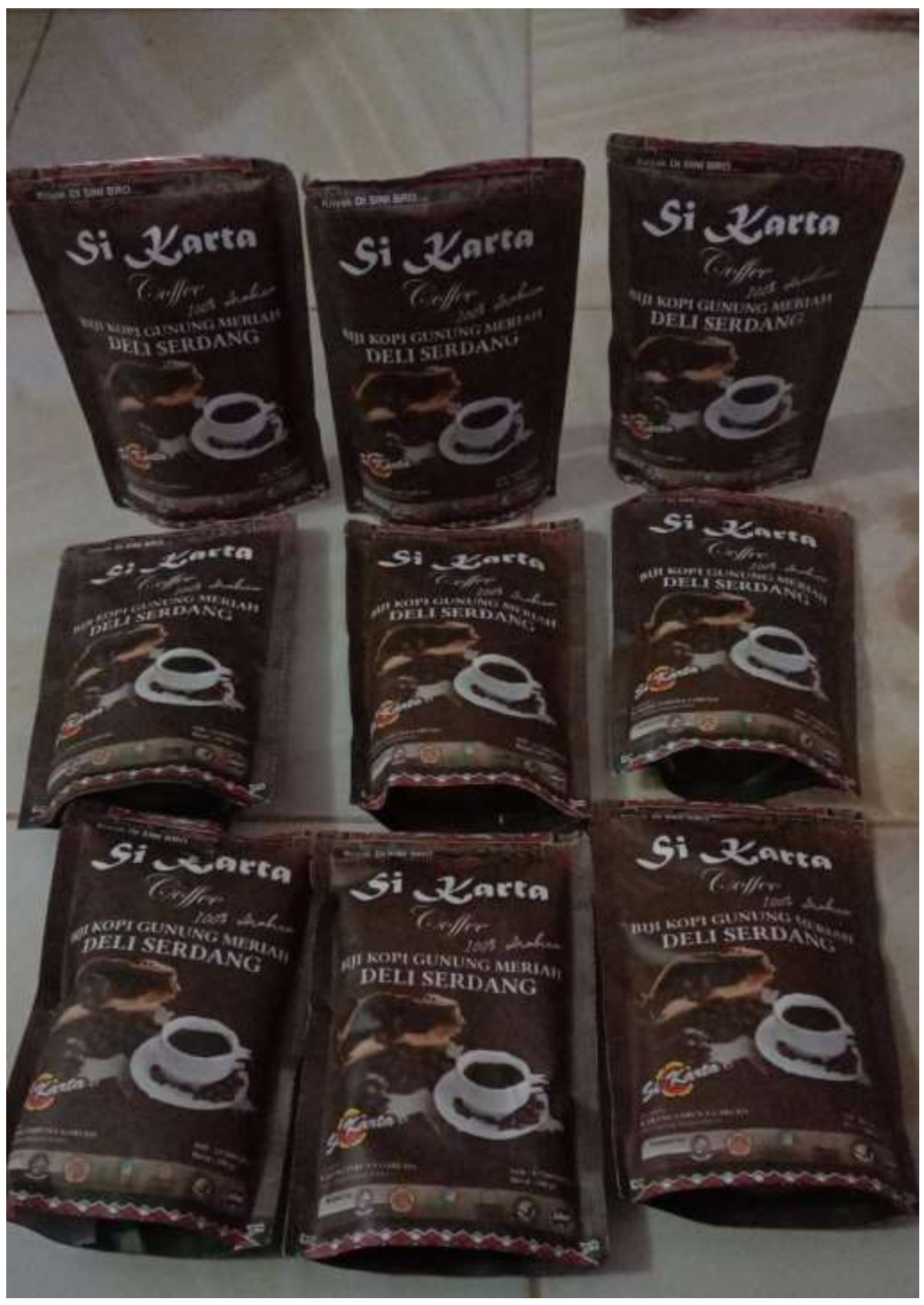

Kopi yang sudah dikemas dan siap dipasarkan

\section{(c) (1) (2)}

JURNAL WIDYA This work is licensed under a Creative Commons Attribution-NonCommercialShareAlike 4.0 International License. 